\title{
ANALISIS PENGARUH PROGRAM PENINGKATAN PRODUKSI PADI TERHADAP PENDAPATAN PETANI (Studi Kasus di Desa Maccini Baji, Kecamatan Bajeng, Kabupaten Gowa, Provinsi Sulawesi Selatan)
}

\author{
Ayu wulandary ${ }^{1}$ \\ ${ }^{1}$ Prodi Agribisnis Universitas Muhammadiyah Sidenreng Rappang \\ Jl. Angkatan 45 No. 1 A Telp. (0421) 93308 Lt. Salo- Sidrap-Sulawesi Selatan \\ Email: Ayuwulandary916@gmail.com
}

Received: 12 Agustus 2019

Accepted: 3 Oktober 2019

\begin{abstract}
The research aims to intend to determine the amount of rice production and farmers income, the level of efficiency using the means of production as well as to know the effect of increasing rice production program for income of farmers in the village Maccini Baji. This study was conducted from April to June 2018 This research was using structured interviews and observations and sampling was conducted by purposive sampling method (intentionally). Analysis of the data was using descriptive quantitative analysis of income and multiple linear analysis, while the data was using a numeral will be tabulated and be treated by using the analysis tools. The results showed production of rice farming in the village Maccini Baji, this classified the medium category, and this is because there are some members of the group of farmers who still have a narrow field with an average net income of Rp.33,495,617/Ha/Thn. The great level of efficiency using of production facilities to increase rice production programs for the revenue of farmers in the Maccini Baji village, that the use of the means production are Seed, KCL, ZA, NPK, DMA, Arrivo Lindomin, Decis and Rackus is not efficient because NPM has factor $>1$ while urea's using production facilities are inneficient because has factor $<1$. And programs to increase rice production by T-test factors amount no variables significantly affect the income of farmers in the village Maccini Baji, Bajeng Sub-District, Gowa District, South Sulawesi Province.
\end{abstract}

Keywords: Paddy, Production, Income, Efficiency.

\begin{abstract}
ABSTRAK
Penelitian ini bertujuan untuk mengetahui besarnya produksi dan pendapatan usahatani padi, tingkat efesiensi penggunaan sarana produksi serta Mengetahui pengaruh program peningkatan produksi padi terhadap pendapatan petani di Desa Maccini Baji. Penelitian ini dilakukan pada bulan april sampai juni 2018 penelitian ini dilakukan dengan menggunakan metode wawancara terstruktur dan Observasi serta pengambilan sampel dengan metode purposive sampling (sengaja), analisis regresilinear berganda untuk melihat pengaruh program peningkatan produksi padi. Sedangkan data yang menggunakan angka akan ditabulasi dan diolah dengan menggunakan alat analisis tersebut. Hasil penelitian menunjukkan Produksi usahatani padi di Desa Maccini Baji, termasuk kategori sedang, hal ini disebabkan karena ada sebagian dari anggota kelompok tani yang masih memiliki lahan sempit dengan rata-rata pendapatan bersih sebesar Rp. 33.495,617/Ha/Thn. Tingkat efisiensi penggunaan sarana produksi pada program peningkatan produksi padi terhadap pendapatan petani di Desa Maccini Baji menunjukkan penggunaan sarana produksi benih, KCL, ZA, NPK, DMA, Arrivo, Lindomin, Decis dan Rackus belum efisien dikarenakan NPM factor produksi $>1$, sedangkan penggunaan sarana produksi pupuk urea tidak efisien dikarenakan NPM faktor produksi $<1$. Dan program peningkatan produksi padi berdasarkan uji-T faktor tidak ada variabel yang berpengaruh secara nyata terhadap pendapatan petani di Desa Maccini Baji, Kecamatan Bajeng, Kabupaten Gowa.
\end{abstract}

Kata Kunci: Padi, Produksi, Pendapatan. Efisiensi

\section{PENDAHULUAN}

Indonesia merupakan negara agraris yang sebagian besar penduduknya bermata pencaharian disektor pertanian, sektor pertanian mempunyai peranan yang sangat penting dalam perekonomian nasional, hal ini terlihat dari banyaknya jumlah penduduk Indonesia yang hidup dan bekerja disektor tersebut.

Tujuan pembangunan pertanian adalah untuk meningkatkan produksi pertanian guna memenuhi kebutuhan pangan dan industri dalam negeri, meningkatkan ekspor, pendapatan petani, memperluas lahan pekerjaan dan mendorong 
pemerataan berusaha. Seiring dengan meningkatnya pembangunan nasional terutama dalam memenuhi kebutuhan pangan maka permintaan bahan pangan pun meningkat, mengingat sumber daya alam yang besar pada sektor pertanian maka di masa mendatang sektor ini masih merupakan sektor penting dalam memberikan konstribusi pada pertumbuhan ekonomi nasional

Pertanian adalah suatu jenis produksi yang berlandaskan pada pertumbuhan tanaman, hewan, dan ikan. Dalam arti luas pertanian adalah pengelolaan tanaman, hewan dan ikan serta lingkungannya agar memberikan suatu produk. Sedangkan dalam arti sempit pertanian adalah pengelolaan tanaman dan lingkungannya agar memberikan suatu produk.

Sulawesi Selatan merupakan daerah penghasil tanaman pangan terbesar di Kawasan Timur Indonesia. Predikat sebagai lumbung padi nasional mengukuhkan posisi Sulawesi Selatan sebagai produsen tanaman pangan yang cukup potensial. Sebagian besar produksi padi Sulawesi Selatan dihasilkan oleh jenis padi sawah. Jenis padi ini menyumbang 99,60 persen dari seluruh produksi padi atau sebesar 3.352.117 ton. Areal pertanian di provinsi ini mencapai 1.411.446 ha, terbagi dalam lahan persawahan seluas 550.127 ha dan lahan kering seluas 861.319 ha. Produksi beras setiap tahunnya menghasilkan 2.305469 ton, dimana 884.375 ton hanya dikonsumsi lokal dan sisanya 1.421 .094 ton merupakan cadangan yang didistribusikan di Kawasan Timur Indonesia (Dinas Pertanian, 2017).

Kabupaten Gowa telah memberi kontribusi nyata dalam mempertahankan swasembada beras di Sulawesi Selatan dan memberi sumbangan bagi surplus beras Sulsel 2 juta ton. Berdasarkan hasil surplus produksi beras Kabupaten Gowa tahun 2017, perhitungan surplus beras tingkat nasional dimana produksi (gabah kering giling) berkisar 335.152 ton dengan kebutuhan benih 1.399 ton sedangkan untuk surplus/minus produksi 86.084 ton,untuk tingkat swasembada (tersedia untuk konsumsikebutuhan daerah) $191,71 \%$. Produksi tersebut untuk luas lahan tanam 55.977 hektar (ha) (Dinas Pertanian, 2017). Adapun perkembangan luas panen, produksi, dan produktivitas padi di Kabupaten Gowa dapat dilihat pada Tabel 1.
Tabel 1. Luas Panen, Produksi, dan Produktivitas Padi di Kabupaten Gowa Tahun 2017.

\begin{tabular}{|c|c|c|c|}
\hline Kecamatan & $\begin{array}{l}\text { Luas } \\
\text { Lahan } \\
(\mathrm{Ha})\end{array}$ & $\begin{array}{l}\text { Produksi } \\
\quad \text { (ton) }\end{array}$ & $\begin{array}{c}\text { Produktivi } \\
\text { tas } \\
\text { (Ton/Ha) }\end{array}$ \\
\hline Somba Opu & 2.209 & 13.912 & 6,29 \\
\hline Palangga & 5.083 & 34.193 & 6,72 \\
\hline Barombong & 3.155 & 17.248 & 5,46 \\
\hline Bajeng & 5.198 & 32.087 & 6,17 \\
\hline Bajeng Barat & 2.812 & 17.811 & 6,33 \\
\hline Bontonompo & 4.385 & 29.108 & 6,63 \\
\hline $\begin{array}{l}\text { Bontonompo } \\
\text { Selatan }\end{array}$ & 3.386 & 19.711 & 5,82 \\
\hline Bontomarannu & 1.707 & 9.781 & 5,73 \\
\hline Pattalassang & 4.217 & 25.756 & 6,10 \\
\hline Parangloe & 2.077 & 11.374 & 5,47 \\
\hline Manuju & 2.418 & 13.722 & 5,67 \\
\hline Tinggimoncong & 1.891 & 9.534 & 5,04 \\
\hline Parigi & 2.066 & 14.241 & 6,89 \\
\hline Tombolo Pao & 2.831 & 19.642 & 6,93 \\
\hline Tompobulu & 4.594 & 24.338 & 5,29 \\
\hline Biringbulu & 1.847 & 11.989 & 6,49 \\
\hline Bungaya & 3.269 & 16.024 & 4,90 \\
\hline Bontolempangan & 2.832 & 14.681 & 5,18 \\
\hline Total 2017 & 55.977 & 335.152 & 5,98 \\
\hline
\end{tabular}

Sumber : Badan Pusat Statistik, 2018

Pada Tabel 1 terlihat bahwa Kecamatan Bajeng merupakan salah satu daerah di Kabupaten Gowa yang memiliki tingkat produksi padi yang tinggi dan menerapkan program peningkatan produksi. Pemerintah Propinsi Sulawesi sejak tahun 2008 telah mencenangkan program surplus beras 2 juta ton, yang ditindak lanjuti masing-masing kabupaten sesuai potensi dan kompetensi yang dimiliki. Namun tantangan dan permasalahan yang dihadapi adalah rendahnya tingkat produktivitas usahatani sebagai akibat dari rendahnya adopsi dan penerapan teknologi pertanian. Ini disebabkan rendahnya kualitas sumber daya manusia serta minimnya sarana dan prasarana yang dapat menunjang kegiatan pembangunan pertanian sehinga petani sulit mengakses informasi teknologi dan pasar.

Sebagai ansitisipasi dan berbagai permasalahan yang dihadapi serta untuk mendukung program pemerintahan pusat dan propinsi Sulawesi selatan tersebut diatas. Pemerintah kabupaten gowa melalui dinas pertanian bersama seluruh komponen masyarakat mampu menciptakan suasana yang kondusif bagi terselenggaranya pembangunan daerah sejak dari perencanaan hingga proses monitoring dan evaluasi sehingga diharapkan bahwa setiap 
program pembangunan dapat terwujud dengan baik.

Salah satu program pertanian dalam rencana strategis Dinas Pertanian Kabupaten Gowa 2015-2020 adalah program peningkatan produksi pertanian yang mencakup penyediaan sarana produksi pertanian dan penggunaan benih unggul berangkat dari sinilah penulis ingin melihat sejauh mana pengaruh program ini dengan melakukan penelitian yang berjudul "Analisis Pengaruh Program Peningkatan Produksi Padi Terhadap Pendapatan Petani". Berdasarkan uraian pada latar belakang, maka tujuan dari penelitian ini yaitu melihat bagaimana pengaruh program peningkatan produksi padi terhadap pendapatan petani di Desa Maccini Baji, Kecamatan Bajeng, Kabupaten Gowa.

\section{Penentuan Sampel}

\section{BAHAN DAN METODE}

Populasi pada penelitian ini adalah semua petani padi yang menjadi anggota Kelompok Tani yang ada di Desa Maccini Baji, Kecamatan Bajeng, Kabupaten Gowa. Tercatat sebanyak 23 kelompok tani yang masing-masing beranggotakan sebanyak 25 petani. Tercatat sebanyak 23 kelompok tani yang masing-masing beranggotakan sebanyak 25 petani, Akan tetapi pada musim tanam pertama (Desember 2017 April 2018) hanya ada 5 kelompok tani yang mendapatkan bantuan dari program Peningkatan produksi, dimana masing-masing kelompok tani beranggotakan 25 orang. Jadi jumlah populasi keseluruhan sebanyak 125 petani padi. Pengambilan sampel dilakukan secara purposive sampling (sengaja), dimana setiap kelompok tani diambil 11 orang anggota kelompok tani sehingga jumlah sampel yang digunakan adalah 55 orang.

\section{Analisis Data}

Analisis data yang digunakan adalah analisis regresi linear berganda. Dimana data yang diperoleh dari hasil praktek lapang akan memberikan penggambaran terhadap petani padi yang ada di desa Maccini Baji, Kecamatan Bajeng, Kabupaten Gowa. Sedangkan data yang menggunakan angka akan ditabulasi dan diolah dengan menggunakan analisis sebagai berikut.

Untuk menganalisis pengaruh program peningkatan produksi padi terhadap pendapatan petani di Desa Maccini Baji, Kecamatan Bajeng, Kabupaten Gowa digunakan analisis pendapatan pada tujuan pertama untuk mengetahui besarnya pendapatan petani serta jumlah produksi yang digunakan. Selanjutnya digunakan model regresi linear berganda karena terdapat lebih dari satu variabel bebas untuk mengetahui pengaruh program terhadap pendapatan. Hubungan tersebut secara umum dapat dijabarkan sebagai berikut :

$\mathrm{Y}=\mathrm{a}+\mathrm{b}_{1} \mathrm{X}_{1}+\mathrm{b}_{2} \mathrm{X}_{2}+\ldots+\mathrm{b}_{\mathrm{n}} \mathrm{X}_{\mathrm{n}}$

Keterangan :

$\mathrm{Y}=$ Pendapatan $(\mathrm{Rp})$

a $\quad=$ Konstanta

$\mathrm{b} 1, \mathrm{~b} 2=$ Koefisien Regresi

$\mathrm{X} 1=$ Lama Program (Bulan)

$\mathrm{X} 2=$ Jumlah Bantuan benih $(\mathrm{Kg})$

X3 = Keaktifan Petani

Untuk mengetahui apakah variabelvariabel bebas berpengaruh terhadap variabel tidak bebas maka dapat dilakukan pengujian statistik, melalui analisis varians (Uji-F) dan uji parsial (Uji-T) serta uji koefisien determinasi (R2). Analisis regresi bertujuan untuk menunjukkan ada tidaknya hubungan linear yang berarti antara variabel bebas $(\mathrm{X})$ dengan variabel tak bebas (Y) dimana kriteria pengambilan keputusan adalah sebagai berikut :

1. Apabila F-Hitung lebih kecil dari F-Tabel maka variabel $\mathrm{X}$ secara bersama-sama tidak berpengaruh terhadap variabel $\mathrm{Y}$, dan sebaliknya apabila $\mathrm{F}$ - Hitung lebih besar atau sama dengan $\mathrm{F}$ - Tabel, maka varibel $\mathrm{X}$ secara bersama-sama maka akan berpengaruh nyata pada taraf kepercayaan 9\% terhadap variabel $\mathrm{Y}$.

2. Apabila $\mathrm{T}-$ Hitung lebih besar atau sama dengan $\mathrm{T}$ - Tabel maka variabel $\mathrm{X}$ secara terpisah (variabel lain konstan) berpengaruh nyata pada taraf kepercayaan $95 \%$ terhadap variabel $\mathrm{Y}$, dan sebaliknya apabila $\mathrm{T}-$ Hitung lebih kecil dari pada T - Tabel, maka masing-masing variabel $\mathrm{X}$ akan terpisah tidak berpengaruh pada variabel Y. Adapun program yang digunakan untuk menganalisis data tersebut adalah program SPSS (Statistical Product and Service Solution) merupakan salah satu program olah data statistik.

\section{HASIL DAN PEMBAHASAN}

\section{Produksi dan Pendapatan Petani Responden}

Produksi adalah proses menggunakan sumberdaya untuk menghasilkan barang-barang, jasa atau kedua-duanya. Produsen dapat menggunakan salah satu atau ketiga faktor produksi (tenaga kerja, modal, dan lahan) itu dengan kombinasi yang berbeda, guna menghasilkan satu atau banyak produk (Mubyarto, 1995). 
Dalam proses produksi terdapat faktorfaktor produksi yang berperan penting sebagai input. Faktor produksi sangat menentukan besar kecilnya produksi yang diperoleh. Dalam kegiatan usahatani, Faktor produksi adalah semua korbanan yang diberikan pada tanaman agar tanaman tersebut mampu tumbuh dan menghasilkan dengan baik. Faktor produksi dikenal pula dengan istilah input, production, factor atau korbanan produksi. Faktor produksi berupa lahan, modal untuk membeli bibit, pupuk, obat-obatan tenaga kerja dan aspek manajemen sangat penting dalam menunjang kegiatan produksi (Soekartawi, 2005). Jumlah produksi yang dihasilkan petani di Desa Maccini Baji, Kecamatan Bajeng dapat dilihat pada Tabel 2.

Tabel 2. Jumlah Produksi Per Tahun Petani Responden di Desa Maccini Baji, Kecamatan Bajeng, Kabupaten Gowa, 2018.

\begin{tabular}{cccc}
\hline No. & $\begin{array}{c}\text { Jumlah Produksi } \\
(\mathrm{Kg} / \mathrm{Ha} / \text { Tahun })\end{array}$ & $\begin{array}{c}\text { Jumlah } \\
(\text { Orang })\end{array}$ & $\begin{array}{c}\text { Persentase } \\
(\%)\end{array}$ \\
\hline 1. & $8.820-11.380$ & 23 & 41.82 \\
2. & $11.381-13.940$ & 27 & 49.09 \\
3. & $13.941-16.500$ & 5 & 9.09 \\
\hline \multicolumn{2}{l}{ Jumlah } & 55 & 100 \\
\hline
\end{tabular}

* Catatan : 1 Tahun $=2 x$ Musim Tanam

Sumber : Data Primer Setelah Diolah, 2018

Berdasarkan data pada tabel 2 dapat dilihat bahwa petani responden yang memiliki produksi 8.820 - 11.380 sebanyak 23 orang dengan persentase $41.82 \%, 11.381-13.940$ sebanyak 27 orang dengan persentase $49.09 \%$, dan petani yang memiliki produksi 9.213 11.672 sebanyak 5 orang atau dengan persentase 9.09\%. Berdasarkan data tersebut dapat disimpulkan bahwa jumlah produksi padi petani responden di Desa Maccini Baji termasuk kategori sedang. Berdasarkan wawancara dengan petani yang menyebabkan produksi petani responden sedang disebabkan karena beberapa hal berikut:

1. Lahan Sempit.

Lahan sempit adalah lahan yang memiliki kurang dari $1 \mathrm{Ha}$. Hal ini yang dialami oleh sebagian besar petani di Indonesia dimana lahan yang dimiliki dari tahun ke tahun semakin sempit. Lahan sempit berpengaruh terhadap produksi rata-rata petani dikarenakan oleh terbatasnya lahan tanam yang berpengaruh langsung terhadap jumlah hasil produksi dari usahatani yang dilakukan.
2. Penggunaan Pupuk Anorganik

Pemakaian pupuk yang baik dan tepat waktu dapat memperbaiki kesuburan tanah dan meningkatka produktivitas padi per hektar. Selama petani lebih banyak menggunakan pupuk anorganik seperti urea,KCL, ZA, dan NPK, daripada pupuk organik seperti kompos dan pupuk kandang. Penggunaan pupuk anorganik ini dapat mengurangi kesuburan tanah sehingga menurunkan produksi padi setiap tahunnya, sedangkan pupuk organik justru dapat memperbaiki kesuburan tanah. Petani lebih memilih menggunakan pupuk anorganik karena pemakaiannya lebih praktis dan hasilnya lebih cepat

\section{Organisme Penganggu}

Organisme penganggu juga dapat menyebabkan rendahnya produktivitas padi per hektar. Jenis dapat berupa seharga ulat, burung, tikus, dan sebagainya. Pemberantasan jenis penganggu mempunyai cara-cara tersendiri sesuai dengan jenisnya. Salah satu jenis penganggu yang banyak merugikan petani adalah jenis serangga. Pemberantasan yang sering dilakukan petani adalah dengan menggunakan pestisida. Jenis pestisida ini bermacam-macam penggunaannya, ukuran, dan waktu pemakaiannya. Penggunaan pestisida yang kurang tepat tidak akan memberikan hasil optimal. Penggunaan pestisida yang tidak proporsional, selain dapat menyebabkan serangga kebal terhadap jenis pestisida, juga dapat menebabkan pencemaran lingkungan. Akibatnya, rata-rata produksi padi perhektar akan megalami penurunan (Tarunoku, 2011).

\section{Pendapatan}

Pendapatan adalah selisih antara nilai produksi dengan jumlah biaya yang dikeluarkan. Pendapatan kotor usahatani dalam jangka waktu tertentu merupakan nilai produksi total usahatani baik dijual maupun tidak dijual. Pendapatan kotor adalah semua pendapatan yang diberikan dalam suatu proses produksi dengan menghitung pengeluaran pada waktu pengelolaan lahan pertanian (Patong, 1991).

Pendapatan usahatani adalah selisih antara penerimaan usahatani dengan biaya total yang dikeluarkan usahatani padi sawah di Desa Maccini Baji selama satu musim tanam yang dinyatakan dalam Rupiah per Hektar per Musim Tanam (Rp/Ha/MT).

Biaya-biaya yang dikeluarkan oleh petani dalam mengelola usahataninya meliputi biaya pembelian pupuk dan pestisida, peralatan produksi serta upah tenaga kerja. Perbedaan 
produksi dengan biaya produksi menyebabkan keuntungan yang diperoleh setiap petani berbeda.

\section{Biaya Usahatani Padi Petani Responden}

Biaya usahatani merupakan seluruh pengeluaran yang terjadi selama jangka waktu tertentu. Biaya usaha ini dibandingkan dengan penerimaan selama jangka waktu tertentu tersebut memperoleh keuntungan atau mengalami kerugian. Setiap usaha selalu diupayakan agar biaya yang dikeluarkan lebih sedikit dari penerimaan. Biaya usaha boleh diperbesar apabila penerimaan menunjukkan kenaikan yang jauh lebih besar lagi (Soekartawi, 1988).

Biaya mempunyai peranan yang amat penting dalam pengambilan keputusan usahatani. Besarnya biaya yang dikeluarkan untuk memproduksi sesuatu menentukan besarnya harga pokok dari produk yang akan dihasilkan, dalam hal ini biaya produksi padi. Jenis biaya yang digunakan dalam analisis biaya usahatani padi yaitu biaya tetap dan biaya variabel. Biaya tetap adalah biaya yang penggunaannya tidak habis dalam satu masa produksi. Tergolong dalam biaya tetap meliputi penyusutan alat dan pajak lahan. Sementara, biaya variabel adalah biaya yang besar kecilnya tergantung kepada skala produksi atau dengan kata lain biaya yang penggunaannya habis atau dianggap habis dalam satu masa produksi. Tergolong dalam biaya variabel adalah biaya sarana produksidan biaya upah tenaga kerja. Jumlah biaya yang digunakan pada usahatani dapat diketahui dengan menggunakan analisis biaya (Aulia, 2008). Biaya usahatani yang digunakan pada masing-masing responden dapat dilihat pada Tabel 3 .

Tabel 3. Biaya Usahatani per Tahun Petani Responden di Desa Maccini Baji, Kecamatan Bajeng, Kabupaten Gowa, Provinsi Sulawesi Selatan, 2018.

\begin{tabular}{clr}
\hline No. & \multicolumn{1}{c}{ Uraian } & Nilai (Rp/Ha) \\
\hline 1. & Biaya Variabel (VC) & \\
& Sarana Produksi & \\
& • $\quad$ Biaya Benih $(\mathrm{Kg})$ & 676,737 \\
& - Biaya Pupuk $(\mathrm{Kg})$ & 947,180 \\
& • $\quad$ Biaya Pestisida & 154,623 \\
& $\quad$ (Botol) & \\
& Biaya Upah Tenaga Kerja & $5,749,233$ \\
& Total Biaya Variabel & $7,572,773$ \\
2. & Biaya Tetap (FC) & \\
& Nilai Penyusutan Alat & 123,635 \\
& Pajak Lahan/Retribusi & 38,982 \\
& Total Biaya Tetap & 162,616 \\
3. & Total Biaya (TC) & $7,410,157$ \\
\hline
\end{tabular}

${ }^{*}$ Catatan : 1 Tahun $=2 \mathrm{x}$ Musim Tanam

Sumber : Data Primer Setelah Diolah, 2018

Berdasarkan data pada tabel 13 dapat dilihat bahwa rata-rata biaya variabel yang dikeluarkan petani responden sebesar $\mathrm{Rp}$ 7,572,773. Dengan jenis biaya benih sebesar Rp. 676,737, biaya pupuk sebesar Rp. 947,180 dan biaya pestisida sebesar Rp. 154,623 sedangkan biaya upah tenaga kerja sebesar Rp. 5,749,233. Biaya tetap yang digunakan petani sebesar Rp. 162.616 dengan rincian biaya NPA sebesar Rp. 123.635 dan pajak lahan sebesar Rp. 38.982 sehingga total biaya yang dikeluarkan oleh petani responden yaitu sebesar Rp 7,410,157. Untuk biaya benih terbantu dengan adanya program pemerintah Dinas Pertanian, Tanaman Pangan dan Peternakan, Kabupaten Gowa dengan mensubsidi biaya benih sebesar $15 \%$ dari harga Rp.50.000/bungkus menjadi Rp.35.000/bungkus.

\section{Penerimaan dan Pendapatan Bersih Usahatani Padi Petani Responden}

Penerimaan usahatani adalah perkalian antara produksi yang diperoleh dengan harga jual. Jumlah produksi adalah hasil yang diperoleh dari cabang usahatani yang diusahakan, sedangkan harga jual adalah nilai atau harga dari usahatani per satuan produksi. Suatu usahatani dikatakan berhasil apabila situasi pendapatan memenuhi persyaratan yaitu cukup untuk membayar semua sarana produksi, untuk membayar upah tenaga kerja atau bentuk lainnya selama proses produksi (Soekartawi, 2003). Penerimaan usahatani yang dihasilkan petani responden terhadap pendapatan petani dapat dilihat pada Tabel 4.

Tabel 4. Penerimaan Per Tahun Usahatani Petani Responden di Desa Maccini Baji, Kecamatan Bajeng, Kabupaten Gowa, 2018.

\begin{tabular}{cccc}
\hline No. & $\begin{array}{c}\text { Penerimaan } \\
\text { Usahatani } \\
(\mathrm{Rp} / \mathrm{Ha} / \text { Tahun })\end{array}$ & $\begin{array}{c}\text { Jumlah } \\
(\text { Orang })\end{array}$ & $\begin{array}{c}\text { Persentase } \\
(\%)\end{array}$ \\
\hline 1. & $\begin{array}{c}27.300 .000- \\
37.450 .000\end{array}$ & 14 & 25.45 \\
& $\begin{array}{c}37.451 .000- \\
2 .\end{array}$ & 36 & 65.45 \\
3. & 47.600 .000 & 5 & 9.10 \\
& 57.750 .000 & 550 & 100 \\
\hline
\end{tabular}

* Catatan : 1 Tahun $=2$ x Musim Tanam

Sumber : Data Primer Setelah Diolah, 2018 
Berdasarkan data pada tabel 14 dapat dilihat bahwa petani responden yang memiliki rata-rata penerimaan usahatani $27,300,000$ $37,450,000$ sebanyak 14 orang dengan persentase $25.45 \%, 37,451,000$ - 47,600,000 sebanyak 36 orang dengan persentase $65.45 \%$ Sedangkan petani yang memiliki rata-rata penerimaan usahatani 47,610,000 - 57,750,000 sebanyak 5 orang atau dengan persentase $9.10 \%$. Hal ini menunjukan bahwa jumlah petani yang memiliki penerimaan usahatani tinggi lebih banyak daripada jumlah petani yang memiliki penerimaan usahatani rendah, hal ini disebabkan oleh jumlah produksi padi yang dihasilkan oleh para petani. Dimana jumlah produksi padi dipengaruhi oleh beberapa penggunaan faktorfaktor produksi.

Penerimaan usahatani padi dihitung dari jumlah output yang dihasilkan dari budidaya padi tersebut. Untuk penghitungan penerimaan usahatani padi, komponen yang dihitung adalah penjualan padi selama satu musim tanam. Jumlah produksi yang dihasilkan dari usahatani padi, mencapai $6.691 \mathrm{~kg} / \mathrm{ha} / \mathrm{thn}$ dalam bentuk gabah kering panen (GKP) dengan harga jual rata-rata Rp. 3.500 perkilogram, penerimaan tunai yang diperoleh petani dari produksi padi adalah Rp 40,905,773 ha/thn.

Pendapatan adalah keuntungan atau hasil bersih yang diperoleh petani dari hasil produksinya. Seorang petani dapat memperoleh keuntungan yang maksimum asalkan petani melakukan tindakan dengan cara meningkatkan hasilnya dengan menekan harga petani melakukan efisiensi teknis dan efisiensi harga yang bersamaan (Daniel, 2002). Pendapatan merupakan balas jasa dari kerjasama faktorfaktor produksi lahan, tenaga kerja, modal, dan pengelolaan. Secara harfiah pendapatan dapat didefinisikan sebagai sisa dari pengurangan nilai penerimaan yang diperoleh dengan biaya yang dikeluarkan.

Menurut Soekartawi (1995), Pendapatan bersih yaitu selisih antara pendapatan kotor dengan semua biaya yang dikeluarkan selama proses produksi (total produksi). Tingkat pendapatan dari usahatani dapat diketahui dengan menggunakan analisis pendapatan pada masing-masing usahatani tersebut. Pendapatan bersih yang diperoleh petani responden dapat dilihat pada Tabel 5.
Tabel 5 Pendapatan Bersih Per Tahun Usahatani Petani Responden di Desa Maccini Baji, Kecamatan Bajeng, Kabupaten Gowa, 2018

\begin{tabular}{cccc}
\hline No. & $\begin{array}{c}\text { Pendapatan bersih } \\
\text { Usahatani } \\
(\text { Rp/Ha/Tahun })\end{array}$ & $\begin{array}{c}\text { Jumlah } \\
(\text { Orang })\end{array}$ & $\begin{array}{c}\text { Persentase } \\
(\%)\end{array}$ \\
\hline 1. & $\begin{array}{c}19,719,383- \\
30,185,089\end{array}$ & 13 & 23.63 \\
2. & $30,185,090-$ & 38 & 69.09 \\
& $40,650,795$ & & 7.28 \\
3. & $40,650,796-$ & 4 & \\
& $51,116,500$ & & 100 \\
\hline
\end{tabular}

*Catatan : 1 Tahun $=2 \mathrm{x}$ Musim Tanam

Sumber : Data Primer Setelah Diolah, 2018

Berdasarkan data pada tabel 5 dapat dilihat bahwa petani responden yang memiliki rata-rata pendapatan usahatani $19,719,838$ sebanyak 13 orang dengan persentase $23.63 \%, 30,185,090-$ $40,650,795$ sebanyak 38 orang dengan persentase $69,09 \%$ Sedangkan petani yang memiliki ratarata penerimaan usahatani 40,650,796 $51,116,500$ sebanyak 4 orang atau dengan persentase $7.28 \%$. Besarnya rata-rata biaya yang dikeluarkan untuk usahatani padi di Desa Maccini Baji sebanding dengan besarnya ratarata penerimaan usahatani padi, sehingga ratarata pendapatan juga lebih besar.

Kegiatan usahatani padi di Desa Maccini Baji yang lebih intensif dan efisien menyebabkan hasil yang didapatkan lebih optimal meskipun rata-rata luas lahan yang digarap lebih kecil, hal ini ditunjang dengan keadaan alam, kesuburan lahan dan motivasi petani serta harga gabah yang lebih tinggi akibat dari mekanisme pasar yang terjadi sehingga mempengaruhi pendapatan para petani responden. Berdasarkan biaya tersebut dapat dikatakan bahwa usahatani yang dilakukan oleh para petani di Desa Maccini Baji sudah menghasilkan output yang dapat memenuhi kebutuhan keluarga ataupun orang lain disamping mencari keuntungan.

\section{Pengaruh Program Peningkatan Produksi Padi Terhadap Pendapatan Petani}

Pendapatan merupakan tujuan akhir dari kegiatan usahatani padi. Dalam kegiatan ini, seorang petani sangat dipengaruhi oleh beberapa faktor dalam usaha meningkatkan pendapatan. Upaya untuk mengetahui beberapa faktor yang dapat berpengaruh dalam pendapatan petani adalah dengan menggunakan uji statistik melalui analisis varians dan uji parsial. Variabel dalam uji statistik untuk melihat beberapa faktor yang berpengaruh dalam pendapatan petani 
yang,terdiri atas variabel terikat (Y) dan variabel bebas (Xi). Dalam peneitian ini, yang menjadi variabel tidak bebas (Y) adalah pendapatan.

Variabel bebas meliputi Lama Program (X1), Jumlah Bantuan benih (X2), dan Keaktifan Petani (X3). Untuk mengetahui pengaruh keseluruhan pengaruh program peningkatan produksi padi terhadap pendapatan maka digunakan analisis variansi (Uji-F) dan untuk mengetahui pengaruh masing-masing antara variabel bebas dan variabel terikat maka dilakukan pengujian statistik melalui Uji parsial (Uji-T). Berdasarkan data pada tabel 15 dapat dilihat bahwa petani responden yang memiliki rata-rata pendapatan usahatani 19,719,838 sebanyak 13 orang dengan persentase $23.63 \%$, $30,185,090$ - 40,650,795 sebanyak 38 orang dengan persentase $69,09 \%$ Sedangkan petani yang memiliki rata-rata penerimaan usahatani 40,650,796 - 51,116,500 sebanyak 4 orang atau dengan persentase $7.28 \%$. Besarnya rata-rata biaya yang dikeluarkan untuk usahatani padi di Desa Maccini Baji sebanding dengan besarnya rata-rata penerimaan usahatani padi, sehingga rata-rata pendapatan juga lebih besar.

Kegiatan usahatani padi di Desa Maccini Baji yang lebih intensif dan efisien menyebabkan hasil yang didapatkan lebih optimal meskipun rata-rata luas lahan yang digarap lebih kecil, hal ini ditunjang dengan keadaan alam, kesuburan lahan dan motivasi petani serta harga gabah yang lebih tinggi akibat dari mekanisme pasar yang terjadi sehingga mempengaruhi pendapatan para petani responden.

Berdasarkan biaya tersebut dapat dikatakan bahwa usahatani yang dilakukan oleh para petani di Desa Maccini Baji sudah menghasilkan output yang dapat memenuhi kebutuhan keluarga ataupun orang lain disamping mencari keuntungan.

\section{Pengaruh Program Peningkatan Produksi Padi Terhadap Pendapatan Petani}

Pendapatan merupakan tujuan akhir dari kegiatan usahatani padi. Dalam kegiatan ini, seorang petani sangat dipengaruhi oleh beberapa faktor dalam usaha meningkatkan pendapatan. Upaya untuk mengetahui beberapa faktor yang dapat berpengaruh dalam pendapatan petani adalah dengan menggunakan uji statistik melalui analisis varians dan uji parsial. Variabel dalam uji statistik untuk melihat beberapa faktor yang berpengaruh dalam pendapatan petani yang, terdiri atas variabel terikat $(\mathrm{Y})$ dan variabel bebas (Xi). Dalam peneitian ini, yang menjadi variabel tidak bebas (Y) adalah pendapatan.
Variabel bebas meliputi Lama Program (X1), Jumlah Bantuan benih (X2), dan Keaktifan Petani (X3). Untuk mengetahui pengaruh keseluruhan pengaruh program peningkatan produksi padi terhadap pendapatan maka digunakan analisis variansi (Uji-F) dan untuk mengetahui pengaruh masing-masing antara variabel bebas dan variabel terikat maka dilakukan pengujian statistik melalui Uji parsial (Uji-T).

Berdasarkan data pada tabel 6 dapat dilihat bahwa hasil analisis data menggunakan program SPSS 21 dapat ditulis persamaan regresi linear sebagai berikut:

$\mathrm{Y}=78816.814 \mathrm{X}_{1}+111238.893 \mathrm{X}_{2}+$ 110967.431X $\mathrm{X}_{3}$. Menggunakan nilai $\mathrm{R}^{2}$ dapat diketahui tingkat signifikansi atau kesesuaian hubungan antara variabel bebas dan variabel terikat dalam model regresi yang dihasilkan. Maka diperoleh nilai $\mathrm{R}^{2}$ sebesar $0.061=0,61 \%$ yang berarti kesesuaian variabel penelitian terhadap model regresi yang dihasilkan artinya sebesar $0,61 \%$ dipengaruhi oleh variabel bebas dan variabel terikat sedangkan $99.94 \%$ dipengaruhi oleh variabel lain.

Tabel 6. Hasil Analisis Regresi Linear Berganda Pengaruh Program Peningkatan Produksi Padi Di Desa Maccini Baji, Kecamatan Bajeng, Kabupaten Gowa, 2018.

\begin{tabular}{|c|c|c|c|c|}
\hline No & $\begin{array}{c}\text { Variabel } \\
\text { Independen }\end{array}$ & $\begin{array}{l}\text { Koefisien } \\
\text { Regresi }\end{array}$ & $\begin{array}{c}\mathrm{T}- \\
\text { Hitung }\end{array}$ & Sig. \\
\hline 1 & $\begin{array}{l}\text { Lama } \\
\text { program }\end{array}$ & 78816.814 & 1.098 & \multirow{3}{*}{$\begin{array}{l}0.256 \\
0.194 \\
0.613\end{array}$} \\
\hline 2 & $\begin{array}{l}\text { Jumlah } \\
\text { Bantuan }\end{array}$ & 111238.893 & -1.226 & \\
\hline 3 & $\begin{array}{l}\text { Keaktifan } \\
\text { Petani }\end{array}$ & 110967.431 & 0.414 & \\
\hline
\end{tabular}

R-Square $=0,061 \quad$ Tt-tabel $=1,675$

t-tabel $=1,675$

F Hitung $=1.107 \quad F$ tabel $=2,79$

Sumber : Data Primer Setelah Diolah, 2018.

Hasil analisis data dapat juga diketahui bahwa nilai F-Hitung adalah 1.107 sedangkan Ftabel 2,79 yang berarti F-Hitung > F-Tabel. Hal ini berarti bahwa variabel bebas seperti lama program, jumlah bantuan benih dan keaktifan petani secara keseluruhan berpengaruh nyata terhadap variabel terikat dalam hal ini pendapatan petani.

Berikut ini dijelaskan secara parsial faktor-faktor pengaruh program peningkatan produksi padi yang mempengaruhi pendapatan petani. 


\section{Lama Program $\left(\mathrm{X}_{1}\right)$}

Program peningkatan produksi pertanian adalah salah satu program Pemerintah Kabupaten Gowa yang dilaksanakan oleh Dinas Pertanian Kabupaten Gowa. Program ini bertujuan untuk meningkatkan hasil produksi khususnya tanaman Padi. Program ini telah berjalan selama 4 tahun.

Tabel 6 menjelaskan bahwa lama program tidak berpengaruh terhadap pendapatan petani. Hal ini dilihat dari nilai t-hitung sebesar 1.098 dan t-tabel sebesar 1,675 yang berarti nilai t-hitung < t-tabel. Lama program tidak berpengaruh terhadap pendapatan petani responden karena semakin lama suatu program maka kualitas dari program tersebut biasanya menurun. Terkadang suatu program tidak mengalami perubahan dari tahun ke tahun. Hal ini dikarenakan pelaku dari program tersebut biasanya hanya bertindak maksimal pada awal pelaksanaan program.

Selain itu, petani responden juga biasanya merasa jenuh apabila program yang dilaksanakan tidak memberikan pengaruh yang nyata terhadap usahatani padinya. Selain itu, para petani yang tergabung dalam program ini memiliki sifat ketergantungan kepada program sehingga identitas kemandirian petani sedikit demi sedikit berkurang dan berdampak pada proses usahatani yang kurang maksimal yang pada akhirnya berpengaruh pada kurangnya pendapatan petani.

2. Jumlah Bantuan Benih $\left(\mathrm{X}_{2}\right)$

Jumlah bantuan yang diberikan oleh dinas pertanian berupa subsidi benih yang selalu diberikan ketika petani ingin melakukan penanaman. Pemberian benih ini disalurkan melalui kelompok tani. Dinas Pertanian, Tanaman pangan, dan Peternakan Kabupaten Gowa memberikan subsidi benih kepada petani sebesar $15 \%$ dari harga benih.

Tabel 5 menjelaskan bahwa jumlah bantuan benih bersubsidi tidak berpengaruh terhadap pendapatan petani. Hal ini dilihat dari nilai t-hitung sebesar -1.226 dan t-tabel sebesar 1,675 yang berarti nilai t-hitung < $\mathrm{t}$-tabel. Jumlah bantuan dalam hal ini benih bersubsidi tidak berpengaruh terhadap pendapatan petani responden karena bantuan benuh yang datang ke Desa Maccini Baji selalu terlambat datang sehingga saat musim tanam banyak petani yang menggunakan benih yang mereka simpan dan sebagian dibeli.

3. Keaktifan Petani $\left(\mathrm{X}_{3}\right)$

Keaktifan petani yang ada di Desa Maccini Baji sudah tergolong bagus hal ini dikarenakan banyaknya petani yang mengikuti penyuluhan yang dilaksanakan oleh Dinas Pertanian Kabupaten Gowa. Penyuluh yang ada di Dinas Pertanian Kabupaten Gowa biasanya melakukan penyuluhan kepada petani sebanyak 2 kali dalam sebulan. Petani yang ada di Desa Maccini Baji sering mengikuti penyuluhan dikarenakan materi yang diberikan oleh penyuluh sesuai yang dibutuhkan petani.

Tabel 5 menjelaskan bahwa keaktifan petani tidak berpengaruh terhadap pendapatan petani. Hal ini dilihat dari nilai t-hitung sebesar 0.414 dan t-tabel sebesar 1,675 yang berarti nilai t-hitung < t-tabel. Hal ini disebabkan karena para anggota kelompok tani malas mengikuti kegiatan penyuluhan dari pemerintah setempat. Program penyuluhan yang biasa diadakan hanya diikuti beberapa anggota kelompok tani saja yang merupakan pengurus inti dari kelompok tani tersebut. Hal itu disebabkan oleh para petani merasa lebih berpengalaman dalam hal berusahatani dibandingkan para penyuluh yang hanya memberikan teori usahatani. Selain itu, kesadaran petani masih kurang akan pentingnya ilmu, mereka hanya ingin mengikuti kegiatan penyuluhan ketika ada bantuan yang didapatkan baik berupa materi maupun barang.

Studi terdahulu menjelaskan tentang studi yang sebelumnya pernah meneliti mengenai faktor-faktor yang mempengaruhi produksi dan pendapatan petani sawah. Penelitian ini dilakukan oleh saudari Andi Rahmi Ismayani yaitu merupakan mahasiswi pada Fakultas Pertanian Universitas Hasanuddin. Adapun judul penelitian ini yaitu "Faktor-Faktor Yang Mempengaruhi Produksi Dan Pendapatan Petani Sawah (Studi Kasus Di Kelurahan Maccini Baji, Kecamatan Lau, Kabupaten Maros, Propinsi Sulawesi Selatan) yang dilakukan pada tahun 2018.

Penelitian ini menjelaskan tentang faktorfaktor yang mempengaruhi produksi dan pendapatan di Kecamatan Lau yang merupakan salah satu daerah penghasil beras di Kabupaten Maros Provinsi Sulawesi Selatan. Tujuan dari penelitian ini adalah untuk mengetahui produksi dan pendapatan petani pada usahatani padi sawah dan untuk mengetahu faktor sosial dan ekonomi terhadap produksi dan pendapatan petani. Dari hasil penelitian menunjukkan bahwa produksi dan pendapatan petani pada usahatani padi sawah di Kelurahan Maccini Baji, Kecamatan Lau, Kabupaten Maros tergolong tinggi dengan ratarata produksi per 0,98 ha sebesar $5.297,14 \mathrm{~kg}$ dan rata-rata pendapatan sebesar Rp. 10.292.214,68. 
Selain itu, faktor sosial berpengaruh nyata terhadap variable tidak bebas (produksi) pada usahatani padi sawah. Secara Parsial, variabel yang berpengaruh signifikan terhadap produksi, yaitu tingkat pendidikan. Dan juga faktor ekonomi tidak berpengaruh nyata terhadap nyata terhadap variable yang berpengaruh signifikan terhadap pendapatan, yaitu biaya produksi dan jumlah produksi.

Penelitian dilakukan menggunakan studi kasus yang ditetapkan adalah daerah sentra produksi padi sawah Kabupaten Maros, yaitu Kecamatan Lau. Sampel desa ditetapkan di Kelurahan Maccini Baji. Objek penelitian adalah petani padi sawah. Data yang dikumpulkan meliputi data primer, yaitu data yang diperoleh dari lokasi penelitian baik melalui observasi maupun wawancara langsung melalui petani responden ataupun dengan menggunakan kuesioner.

Selain itu, data yang digunakan adalah data sekunder, yaitu data yang diperoleh dari lembaga-lembaga terkait seperti Badan Pusat Statistik Kota Makassar (BPS), Dinas Pertanian Dan Hortikultura Kabupaten Maros, Kantor Kelurahan Maccini Baji, serta Balai Penyuluhan Pertanian Kabupaten Maros. Sampel sebanyak 35 orang dikumpulkan secara random di Kelurahan Lau dengan pertimbangan bahwa lokasi tersebut adalah sentra produksi dengan produktivitas yang tinggi. Penentuan sampel dilakukan secara acak sederhana (Simple Random Sampling). Produksi dan pendapatan petani pada usahatani padi sawah di Kelurahan Maccini Baji, kecamatan Lau, Kabupaten Maros tergolong tinggi dengan rata-rata produksi per 0,98 ha sebesar $5.297,14 \mathrm{~kg}$ dan rata-rata pendapatan sebesar Rp. 10.292.214,68. Faktor sosial berpengaruh nyata terhadap variabel tidak bebas (produksi) pada usahatani padi sawah. Secara parsial, variabel yang berpengaruh signifikan terhadap produksi, yaitu tingkat pendidikan. Selain itu juga, faktor ekonomi tidak berpengaruh nyata terhadap variabel tidak bebas (pendapatan). Secara parsial, variabel yang berpengaruh signifikan terhadap pendapatan, yaitu biaya produksi dan jumlah produksi.

Dalam hal peningkatan produksi padi, kebijakan pemerintah yang harus diperhatikan yaitu kebijakan subsidi harga pupuk. Perlu diketahui bahwa dalam komponen produksi padi, pupuk menjadi faktor penentu keberhasilan, yakni mencapai $55 \%$. Dengan kendala sulitnya petani memperoleh suplai pupuk yang memadai, baik harga, jumlah, maupun ketepatan waktu, dibutuhkan suatu terobosan strategis di tingkat kebijakan pemerintah maupun inovasi teknologi. Selain itu, kendala lain yang dihadapi petani di Indonesia dalam mengembangkan usahanya adalah terbatasnya modal dan lemahnya akses terhadap sumber permodalan. Modal juga merupakan kendala dalam memenuhi sarana produksi tanaman terutama benih unggul, pupuk dan pestisida.

Dinas Pertanian berperan penting dalam kerjasama dengan institusi terkait lainnya dalam menghadapi masalah bertambah langkanya sumber air yang mengakibatkan lambatnya pertumbuhan hasil pertanian yang teririgasi. Tantangan dalam menghadapi langkanya sumber air diperbesar dengan terus bertambahnya biaya dalam penyediaan sumber air yang baru, pencemaran tanah di daerah irigasi, penipisan persediaan air tanah, polusi air dan penurunan mutu ekosistem yang berhubungan dengan air, serta pemborosan penggunaan air di tempat suplai air yang telah selesai dibangun (Rosegrant, M.W. dan Hazell, P.B. 2000).

Program peningkatan produksi merupakan dasar dari pembangunan pertanian karena akan menjawab pertanyaan, apa dibisniskan jika tidak ada produksi. Program ini akan mendorong peningkatan produksi hasil pertanian baik jumlah maupun mutunya. Kegiatan program peningkatan produksi meliputi: pengembangan sistem pembenihan nasional, peningkatan produktivitas, perluasan areal tanam, areal tangkap, areal budidaya ikan, peningkatan populasi ternak (antara lain melalui inseminasi buatan), rehabilitas tanaman, replating, diversifikasi, rotasi tanaman, dan lain-lain (Ishak, 2003).

\section{KESIMPULAN}

Produksi usahatani padi di Desa Maccini Baji, Kecamatan Bajeng, Kabupaten Gowa termasuk kategori sedang, hal ini disebabkan karena ada sebagian dari anggota kelompok tani yang masih memiliki lahan sempit dengan ratarata pendapatan bersih sebesar Rp. 33.495.617/Ha/Thn. Berdasarkan uji-F keseluruhan faktor-faktor program peningkatan produksi padi dan berdasarkan uji-T tidak ada faktor yang berpengaruh secara nyata terhadap pendapatan petani di Desa Maccini Baji, Kecamatan Bajeng, Kabupaten Gowa. 


\section{DAFTAR PUSTAKA}

Badan Pusat Statistik (BPS) diakses dari http://www.bps.go.oid/, diakses pada tanggal 2 April 2018.

Budiarta 2017. Peran Kelompok Tani Terhadap Pendapatan Usahatani Padi Di Desa Purwosari Kecamatan Torue Kabupaten Parigi Moutong. Jurnal.untad.ac.id. Vol:5, No 1.

Dinas Pertanian Gowa, 2017. Kabupaten Gowa dalam Angka 2017.

Daniel, Moehar. 2002. Pengantar Ekonomi Pertanian, PT Bumi Aksara, Jakarta.

Febriansyah, Fathoni, Nurchaini 2018.Pengaruh Program Desa Mandiri Pangan Dalam Meningkatkan Pendapatan Usahatani. Jurnal ilmiah sosial-ekonomi bisnis. Vol 21. No 1

Mubyarto. 2001. Pengantar Ekonomi Pertanian. Penelitian Pendidikan dan Penerapan Ekonomi Sosial. Jakarta.

Rosegrant, M. W. dan P.B. Hazell, 2000. Transforming the Rural Asian Economy. Oxford University Press, England.

Soekartawi, 1993. Prinsip Dasar Ekonomi Pertanian. Rajawali Press. Jakarta.

Tarunoku. 2011. faktor yang mempengaruhi produksi padi.https://tarunoku.wordpress.co $\mathrm{m} / 2011 / 11 / 28 /$ faktor-yang mempengaruhiproduksi-padi/. Diakses pada 31 Juli 2018. Makassar 